\title{
The high level of parents' attention in vocational school student career planning
}

\author{
Atikah Rahmah Nasution ${ }^{\left.1^{*}\right)}$, A. Muri Yusuf ${ }^{1}$, Febri Wandha Putra ${ }^{2}$ \\ ${ }^{1}$ Prodi Bimbingan dan Konseling, Fakultas Ilmu Pendidikan, Universitas Negeri Padang, Padang, Indonesia \\ ${ }^{2}$ Prodi Bimbingan Konseling Islam, Fakultas Ilmu Tarbiyah, Institut Agama Islam Sumatera Barat, Pariaman, Indonesia
}

\begin{tabular}{l} 
Article Info \\
\hline Article history: \\
Received May $24^{\text {th }}, 2021$ \\
Revised Oct $23^{\text {rd }}, 2021$ \\
Accepted Nov $02^{\text {nd }}, 2021$ \\
\hline
\end{tabular}

\section{Keyword:}

Career planning

Parents attention

Vocational students

\begin{abstract}
This study aims to determine the attention of parents in student career planning. This type of research is quantitative with a descriptive approach. The population in this study were students of class X SMK, amounting to 231 people. The research sample was taken using purposive sampling technique by using the criteria of students who live with their parents. So that the sample size is 171 students. The instrument in this study was a Likert scale model with five alternative answers and a questionnaire containing statements about parental attention in student career planning. Data were analyzed using the Rasch Model application and using descriptive statistics. The results of the study show that the parental attention instrument is very good for measuring the parental attention that students have. In addition, the results also show that there are students who have parental attention who are in the medium, high, very high, and low categories.
\end{abstract}

(C) 2021 The Authors. Published by IICET.

This is an open access article under the CC BY-NC-SA license

(https://creativecommons.org/licenses/by-nc-sa/4.0

\section{Corresponding Author:}

Atikah Rahmah Nasution

Universitas Negeri Padang

Email: atikah.rahmah.nst@gmail.com

\section{Introduction}

Career planning is an activity that is carried out in a directed and focused manner based on the potential that is owned to advance and develop, both in quality and quantity. Individuals who have career plans that match their talents and interests will be better prepared to face the future associated with their career life (Sukardi, 2003). Individuals need to have prior planning and effort in reaching their career, because the highest career can't be achieved instantly, but must be done with careful planning. Career planning is better done as early as possible, given how important career issues are in life (Rintyastini \& Charlotte, 2006).

However, planning a career is not as easy as imagined. Leksana, Wibowo \& Tadjri (2013) revealed that there are several career problems experienced by vocational students, which are related to choosing the type of education that leads to choosing the type of work, career planning and deciding about future careers and information about existing work groups with requirements that must be owned. This is supported by research Alfionita \& Naqiyah (2014) which shows that there are still vocational students who experience confusion in planning their careers, even though they have occupied the major they have chosen and there are also students who could not merge their career planning according to their potential so they are still confused about what they should do after graduating from school. Later in which they will face having to decide in a short time, but have reflected little about the things that have to be decided and do not understand the need to process information about themselves and their environment. This is evidenced by the research conducted Anisah 
(2015) which shows that there are students of class XI at SMK Negeri 1 Sayung who have career plans that are in the low category by $48 \%$.

One other problem that causes a child's career to be low is the lack of attention from parents. Based on opinion Ningsih \& Nurrahmah (2016) that parents who have the spare time to educate their children and pay attention to children's development usually have a good effect on children's learning outcomes and children's careers. Meanwhile, parents who pay little attention and do not even have the spare time to educate their children, the tendency of the child's learning achievement will be lower, which causes the child's career to be low. In the family, there is an important role of parents who can support the success of a child's career, namely the attention of parents to their children. A'la (2016) said that parents can be interpreted as two human figures comprising a man and a woman, who have been tied with a marriage rope to become husband and wife and become the main pillar of the birth of a family. From this affectionate relationship between husband and wife, the fruit of love called children is born, which is the responsibility of parents in educating, caring for and raising them. Research conducted by Rainey \& Borders (1997) shows that parents of teenagers are in a position to influence their child's career development, because they have watched their child's development, know their child's interests and strengths and have developed a trusting relationship between the two.

Based on the description above, the problem found is that there are still students who have low career planning and there are still parents who do not care about their children's career planning. So that the purpose of this study is to find out how the attention of parents regarding student career planning.

\section{Method}

This type of research is quantitative with a descriptive approach. The population in this study were students of class X Vocational High School, amounting to 231 students. The research sample was determined using a purposive sampling technique that uses the criteria of students who live with their parents. So that the number of samples in this study were 171 students. The instrument used to collect research data was a Likert scale model with five alternative answers and a questionnaire containing statements about parental concerns regarding student career planning. The data processing of this research used statistical fit analysis through the Rasch Model application ( Alagumalai, Curtis \& Hungi, 2005; Bond, Yan \& Heene, 2020; Sumintono \& Widhiarso, 2015) and using descriptive statistics. Furthermore, the limitation in this study is that it only uses a limited number of samples. And also the samples taken only came from the low class.

\section{Results and Discussions}

The results and discussion of data analysis on parental attention in student career planning will be discussed in detail. For more information, see the discussion below.

The results of testing the quality of the instrument parent's attention in career planning The results of testing the quality of the instrument can be seen in the following table.

Table 1. Summary of Quality Instrument Item

\begin{tabular}{lc}
\hline Estimation & Values \\
\hline Item Reliability & 0.98 \\
Cronbach Alpha (KR-20) & 0.85 \\
Separation indexs of Item & 7.54 \\
Mean INFIT MNSQ Item & 1.00 \\
Mean OUTFIT MNSQ Item & 1.02 \\
Raw variance explained by measures & 42.4 \\
\hline
\end{tabular}

The results of the analysis of the instrument quality test in the table above indicate that the item reliability value is 0.98 . This means that the quality of the instrument items used to measure parental attention in student career planning is at a special level. In addition, the reliability score based on Alpha Cronbach (KR-20) is 0.85 which means that the interaction between respondents and items is excellent. Furthermore, the value of the separation index of items is 7.54 which means that the quality of the instrument in terms of overall respondents and items is good. Then the value of Raw variance explained by measures is $42.4 \%$, this shows that the instrument is able to measure what it should be measured. In addition, the response sensitivity pattern value +1.00 logit (INFIT MNSQ Item) and the overall person response pattern sensitivity value +1.02 logit (OUTFIT MNSQ) indicate that they are in the ideal range $(+0.5<\mathrm{MNSQ}>+1.5)$. Thus it can be concluded that the instrument has a very good quality used to reveal parental attention in student career planning. 
Analysis of Parental Attention in Student Career Planning

Description of research data based on the results of data collection in this study can be seen in the Table 2 .

Table 2. Frequency Distribution and Parents' Attention in Student Career Planning

\begin{tabular}{lccc}
\hline Parents' Attention Category & Score Intervals & f & \% \\
\hline Very High & $\geq 109$ & 20 & 11,70 \\
High & $88-108$ & 92 & 53,80 \\
Middle & $67-87$ & 50 & 29,24 \\
Low & $46-66$ & 9 & 5,26 \\
Very Low & $\leq 45$ & 0 & 0 \\
Total & & $\mathbf{1 7 1}$ & $\mathbf{1 0 0}$ \\
\hline
\end{tabular}

The attention data analysis above shows that as many as $53.80 \%$ of students who pay attention are in the high category. Furthermore, as many as $29.24 \%$ of students paid attention to being in the medium category. Then, as many as $11.70 \%$ of students paid attention to the very high category. And finally, as much as $5.26 \%$ of students paid attention to the low category. From the data from the analysis, it was also found that most of the students who had high attention in preparing their career plans, but there were still students who had people's attention in their career plans.

Parents' attention is the concentration of psychic energy that is focused on an object that is carried out by fathers and mothers to their children in an activity (Nisa, 2017). From the description above, there are still students who have low parental attention. Parents who do not care about their children, parents who do not fulfill their duties as father and mother, will affect the survival of their children. Especially the role of a father and mother in providing education and attention to their children. According to Pratiwi (2017) states the form of parental attention to children's education, namely; a) raising physically and mentally, b) directing and guiding, c) setting an example, d) controlling the mental development of children, e) providing encouragement or motivation, and f) providing learning facilities.

Parents' involvement in providing learning guidance for children and also providing learning facilities, especially textbooks and encouragement to further encourage children's learning (Kurniawan \& Wustqa, 2014). Based on the opinion of Ningsih \& Nurrahmah (2016) that parents who have free time to educate students and pay attention to student development usually have a good effect on student learning outcomes and student careers. Meanwhile, parents who pay little attention and do not even have the spare time to educate their children, the likelihood of the child's learning achievement will be lower, causing student careers to be low. Furthermore, Putra, Yusuf \& Solfema (2019) stated that one form of parental support for student career development is parental attention. Parents are often said to be the first and foremost environment in shaping children's character and also as a place for the first life declaration or the initial foundation (blue print) which will have a tremendous influence on children's lives in the future, the family has a huge influence on character building and children's learning achievement and children's career (Tu'u, 2004). Roe stated that "focused on predicting occupational selection based on psychological needs that develops from the interaction between children and their parents" (Sharf, 2016). It can be understood that Roe focuses on how to predict job selection based on psychological needs that support the development of child-parent interactions, so the need for parental attention to children in planning their careers. So it can be concluded that the attention of parents is needed by students in making career planning. Because parents can become role models for students who will enter the world of work. In addition, by getting your parents' attention, you will be better prepared to make career plans for the future.

\section{Conclusions}

Based on the description above, it can be concluded that there are two, namely; 1) The quality of the instrument of parental attention in student career planning is very good for measuring parental attention in student career planning. 2) The results of research data processing show that overall the parents' attention that students have is in the high category, but there are still students who have parental attention who are in the medium category and some even have parental attention who are in the low category. The implications of the results of this study for guidance and counseling services are increased cooperation or collaboration between guidance and counseling teachers and parents related to student career planning. Because to assist students in preparing career plans is not only the responsibility of teachers in schools, but parents also have the same responsibility in helping students to compile career plans. 


\section{References}

A'la, R. (2016). Perhatian Orang Tua dan Motivasi Belajar Siswa. Madaniyah, 6(2), 242-259.

Alagumalai, S., Curtis, D. D., \& Hungi, N. (2005). Applied Rasch measurement: A book of exemplars. Netherlands: Springer.

Alfionita, Z. R. R., \& Naqiyah, N. (2014). Penggunaan Genogram untuk Meningkatkan Kemampuan Perencanaan Karier Siswa Kelas XI Kompetensi Keahlian Akuntansi SMK Negeri 1 Surabaya. Jurnal $B K, 4(3), 1-8$.

Anisah, L. (2015). Model layanan informasi karir dengan teknik field trip untuk meningkatkan perencanaan karir siswa SMK di kabupaten Demak. Jurnal Konseling GUSJIGANG, 1(1).

Bond, T., Yan, Z., \& Heene, M. (2020). Applying the Rasch model: Fundamental measurement in the human sciences. Routledge.

Kurniawan, D., \& Wustqa, D. U. (2014). Pengaruh perhatian orangtua, motivasi belajar, dan lingkungan sosial terhadap prestasi belajar matematika siswa SMP. Jurnal Riset Pendidikan Matematika, 1(2), $176-187$.

Leksana, D. M., Wibowo, M. E., \& Tadjri, I. (2013). Pengembangan modul bimbingan karir berbasis multimedia interaktif untuk meningkatkan kematangan karir siswa. Jurnal Bimbingan Konseling, 2(1).

Ningsih, R., \& Nurrahmah, A. (2016). Pengaruh kemandirian belajar dan perhatian orang tua terhadap prestasi belajar matematika. Formatif: Jurnal Ilmiah Pendidikan MIPA, 6(1).

Nisa, A. (2017). Pengaruh perhatian orang tua dan minat belajar siswa terhadap prestasi belajar ilmu pengetahuan sosial. Jurnal Faktor UNINDRA, 2(1), 1-9.

Pratiwi, N. K. (2017). Pengaruh tingkat pendidikan, perhatian orang tua, dan minat belajar siswa terhadap prestasi belajar bahasa Indonesia siswa SMK kesehatan di kota Tangerang. Pujangga, 1(2), 31.

Putra, F. W., Yusuf, A. M., \& Solfema, S. (2019). Analysis of parent support in career planning of vocational students. Konselor, 8(2), 47-51.

Rainey, L. M., \& Borders, L. D. (1997). Influential factors in career orientation and career aspiration of early adolescent girls. Journal of Counseling Psychology, 44(2), 160.

Rintyastini, Y., \& Charlotte, S. Y. (2006). Bimbingan dan Konseling SMP untuk Kelas VIII. In Jakarta: Erlangga.

Sharf, R. (2016). Applyig career development theory to counseling. Cole Publishing Company.

Sukardi, D. K. (2003). Manajemen Bimbingan dan Konseling di Sekolah. In Bandung: Alfabeta.

Sumintono, B., \& Widhiarso, W. (2015). Aplikasi Pemodelan Rasch pada Assessment Pendidikan. Trim Komunikata.

Tu'u, T. (2004). Peran disiplin pada perilaku dan prestasi siswa. Jakarta: Grasindo. 